\title{
Renal Biopsies in A Tertiary Health Institution in South-Southern, Nigeria: A Single Multi-National Center Study.
}

\author{
Odigie B.E. $^{1,2}$, Atoigwe B.E. ${ }^{1}$ \\ ${ }^{I}$ Department Of Medical Laboratory Science, School Of Basic Medical Sciences, College Of Medical Sciences, \\ University Of Benin, Benin City, Nigeria, \\ ${ }^{2}$ Department Of Medical Laboratory Science, Faculty Of Health Sciences And Technology, College Of \\ Medicine, University Of Nigeria, Enugu Campus (UNEC), Nigeria
}

\begin{abstract}
Malignant renal tumour is a relatively rare type of cancer that occurs third in urological tumours after prostate and bladder cancers. It is among the leading cancers in western societies and is male predominant, aged (16-80) years with a peak incidence in the 5th and 6th spans of life (45-60 years) than in females. There are limited studies in the literature reporting its existence in South-southern, Nigeria. A little knowledge of its existence is known in Benin City, which propelled this study. The aims of this study were to determine the occurrence and histopathology patterns of malignant renal tumours including the histologic subtypes in a multi-national study centre. This is a 25-year retrospective study spanning from 1991 to 2016; in which the report of 19,123 haematoxylin and eosin stained sections were reviewed. Patient's data (age, sex and ethnicity) were also retrieved from the archives of the histopathology laboratory of the University of Benin Teaching Hospital (UBTH), Benin City, Nigeria and were analysed using the Statistical Package for Social Sciences (SPSS) version 20.0. The result revealed that 69 samples were reconfirmed as renal tumours and a preponderance of males (66.7\%) was observed. Renal cell carcinoma 35/53(66.0\%) has the highest occurrence of malignant renal tumours, and nephroblastoma (20.8\%), which is closely followed by transitional cell carcinoma (13.2\%). This study, therefore, concludes that malignant renal tumour is male predominant while renal cell carcinoma has the highest occurrence in Benin City, Nigeria. However, a significant finding is the report of papillary renal cell carcinoma and clear cell carcinomas, which appeared to be more common in Nigeria than granular cell carcinomas and clear cell type that are predominant in North America.
\end{abstract}

Keyword: Renal disease, renal biopsy, renal tumor, renal cell carcinoma, malignant tumors and Urology.

\section{Introduction}

Renal biopsy has become one of the cornerstones of nephrology practice, been an important means of diagnosing, prognosticating and guiding the treatment of many malignant renal tumors [1]. Globally, 270,000 cases of this tumor are diagnosed yearly while 116,000 people die from the disease [2]. Histologic patterns in many European [3], Asian [4], and American [5] countries are well-known and are published. In Nigeria, low occurrences of malignant renal tumors are reported in Jos (North-central), Port Harcourt (South-southern), and Enugu (South-eastern), Nigeria. The age range of patients with malignant renal tumors in Nigeria have also been reported. Consequently, the highest occurrence of malignant renal tumors in Nigeria occurs much lower than the 50-70 years peak incidence reported in the literature amongst the Caucasian [6]. Glomerulonephritis is reportedly the leading cause of end-stage renal disease in Africa [6]. Slight info is existing on the histological patterns of renal disease in African countries, mainly due to the non-existence of renal biopsy registries in many African countries or because renal biopsy as a tool for diagnosing renal disease is entirely unavailable [7].

There are three main classes of malignant renal tumors: nephroblastomas (NBT), transitional cell carcinomas (TCC) now urothelial cell carcinomas (UCC), and renal cell carcinoma (RCC). Histologically, NBT also known as Wilm's tumor is unruffled of small, primitive-looking cells with dark nuclei little cytoplasm and poorly defined cell borders growing in solid sheets. Urothelial cell carcinomas (UCC) occur in the renal pelvis and are similar to UCC of the bladder [8]. Renal cell carcinoma is a malignant neoplasm having several tumor subtypes, each distinct genetically, and unique clinically. The traditional histology subtypes of RCC are a Clear cell, Granular cell, Sarcomatoid, and Tubulopapillary tumors [8]. Though, World Health Organization classification has over 40 sub-classifications of RCC. However, following a proposal by Kovacs [9] that was later reviewed by Weiss et al. [10], there is the addition of a histology subtype like the chromophobe cell carcinoma that has long been inundated into practice. There is also a reclassification of the granular cell tumor and the sarcomatoid lesions that are now recognized to represent poorly differentiated elements derived from other histology subtypes $[9,10]$.

Among young African-Americans with sickle cell trait, a medullary cell variant of RCC is common [11]. RCC is the main collective malignant tumor of the kidney in adults worldwide [3] and has been described to constitute $1-2 \%$ of all malignant tumor of the kidney in childhood. NBT is the most common malignant tumor 
of the kidney in children, and it is the commonest childhood tumor [9] in some centers in Africa. Histologically, renal cell carcinoma occurs in three most common forms, namely: clear cell carcinomas, papillary renal cell carcinomas, and chromophobe renal cell carcinomas [12]. From the ongoing, however, the present study aims to determine the occurrence and histopathology patterns of malignant renal tumors including the histologic subtypes in a single multi-national study center, in Benin City, Nigeria. However, it is subject to the availability of data according to the pathology diagnosis at the histopathology laboratory in UBTH, Benin City, Nigeria.

\section{Materials And Methods}

Approval for this study was issued by the Ethics and Research Committees, University of Benin Teaching Hospital (UBTH), Benin City, Nigeria (Protocol number: ADM/E22/A/VOL.VII/1241). A 25-year retrospective study of renal samples received in the histopathology laboratory from January 1991 to January 2016 was carried out. The demographic data (age, sex and ethnicity) were obtained from the patient's histology request cards and ledgers; while, stained haematoxylin and eosin (H\&E) slides were also retrieved from the laboratory archives and reviewed subsequently. The classification method by Isah [12] was also adopted. The paraffin-embedded blocks of untraced slides were sorted out, resectioned and then re-stained using the haematoxylin and eosin (H\&E) staining method that was used previously. A total of 19, 123 stained H\&E slides were reviewed blindly by the pathologist (about eight senior residents and two consultants histopathologist) using a Swift ${ }^{(\mathrm{R})}$ binocular light microscope (Olympus, England) at X10 and X40 magnifications respectively.

\subsection{Exclusion criteria}

Histology slides with an incomplete or missing data as well as those ones that are severely damaged and with untraceable paraffin blocks for re-sectioning are excluded from this study.

\subsection{Laboratory Analyses and Duration of Study}

The present study was conducted in the Histopathology Laboratory of UBTH and partly in the Department of Medical Laboratory Science, Histopathology sub-Departmental Laboratory, University of Benin, Nigeria. Manual sorting of the histology slides and paraffin embedded blocks, sectioning, staining, microscopic examination and review of slides by the pathologist lasted for thirty months (January 2014 to June 2016).

\subsection{Data Analysis}

Data was entered into a personal computer and stored on a standard Microsoft ${ }^{\circledR}$ Excel database. The analysis was conducted with the Statistical Package for Social Sciences (SPSS) version 20.0 (Inc. Chicago, Illinois, USA). Percentages were used to express the frequency of cases [13]. Data are also presented as Means \pm SD and analyzed using ANOVA and Duncan post hoc test and the significance was determined at $\mathrm{p}<0.05$.

\section{Results}

Our records showed a total of 19,373 suspected renal tumor histology samples sent to the histopathology laboratory for examination between January 1991 and January 2016. From these records, 53 paraffinized tissue blocks were untraceable (majorly due to a poor storage facility and methods), 197 cases with incomplete data (also due to poor data management systems) while 19,123 slides are available for review. After peer evaluations and examinations, 69 cases were confirmed as renal tumors; constituting 0.36 percent of all the diagnosis made within the period under consideration. The mean age of all malignant tumor cases is 40.2 years, with a higher frequency of instances 15/53(28.3\%) are within the age range of 21-30yrs (Table 1). There are 16 cases of benign lesions ( 8 males and 8 females) representing 16/19,123 (0.08\%) while 53 cases are malignant lesions (31 males and 22 females); which constitute 53/19,123 (0.28\%). The clinical presentation revealed that intra-abdominal mass serves as the highest standard indicator for biopsies $69 / 69(100 \%)$ and necroturia been the least $2 / 69(2.9 \%)$ of all renal biopsies (Table 5). In our study, RCC is the prominent form of kidney tumor occurrence among the Yorubas and other tribes in Nigeria accounting for 12/53(22.6\%) and 34/53(64.2\%) respectively (Table 2). There seems to be a significant distinction in the occurrence of all RCC in the 25 -year period $(P$.037).

\section{TABLES}

Table 1: Age Distribution of the Common Malignant Tumours in Benin City, Nigeria ( $\mathrm{N}=53$ )

\begin{tabular}{|c|c|c|c|c|c|}
\hline Age Range (yr) & $\begin{array}{c}\text { Nephroblastoma } \\
\text { (NBT) }\end{array}$ & $\begin{array}{c}\text { Transitional cell } \\
\text { carcinoma (TCC) }\end{array}$ & $\begin{array}{c}\text { Renal cell } \\
\text { carcinoma } \\
\text { (RCC) }\end{array}$ & $\begin{array}{c}\text { Occurrence } \\
(\%)\end{array}$ \\
\hline $0-10$ & 11 & 00 & 00 & 11 & $20.75 \%$ \\
\hline $11-20$ & 00 & 01 & 00 & 01 & $1.89 \%$ \\
\hline $21-30$ & 00 & 14 & 01 & 15 & $28.30 \%$ \\
\hline $31-40$ & 00 & 01 & 01 & 02 & $3.77 \%$ \\
\hline
\end{tabular}


Renal Biopsies in A Tertiary Health Institution in South-Southern, Nigeria: A Single ...

\begin{tabular}{|c|c|c|c|c|c|}
\hline $41-50$ & 00 & 11 & 03 & 14 & $26.42 \%$ \\
\hline $51-60$ & 00 & 07 & 02 & 09 & $16.98 \%$ \\
\hline $61-70$ & 00 & 01 & 00 & 01 & $1.89 \%$ \\
\hline Total & 11 & 35 & 07 & 53 & $100 \%$ \\
\hline
\end{tabular}

Table 2: Ethnic Distribution of Malignant Renal Tumors in Benin City, Nigeria $(\mathrm{N}=53)$

\begin{tabular}{|c|c|c|c|c|}
\hline Variables & Ibo $(\mathrm{n}=7)$ & Hausa $(\mathrm{n}=0)$ & Yoruba $(\mathrm{n}=12)$ & Others $(\mathrm{n}=34)$ \\
\hline Renal cell carcinoma (RCC) & 04 & 00 & 11 & 20 \\
\hline Nephroblastoma (NBT) & 03 & 00 & 01 & 07 \\
\hline Transitional cell carcinoma (TCC) & 00 & 00 & 00 & 07 \\
\hline Total & 07 & 00 & 12 & 34 \\
\hline Occurrence & $07 / 53$ & $0 / 53$ & $12 / 53$ & $34 / 53$ \\
\hline Percentages (\%) & $13.2 \%$ & $0 \%$ & $22.6 \%$ & $64.2 \%$ \\
\hline
\end{tabular}

Table 3: Sex distributions of different types of renal malignancy $(\mathrm{N}=53)$

\begin{tabular}{|c|c|c|}
\hline Variables & Males & Females \\
\hline Renal cell carcinoma (RCC) & 22 & 13 \\
\hline Nephroblastoma (NBT) & 09 & 02 \\
\hline Transitional cell carcinoma (TCC) & 07 & 00 \\
\hline Occurrence & 38 & 15 \\
\hline Percentage (\%) & $71.7 \%$ & $28.3 \%$ \\
\hline
\end{tabular}

Table 4: Common Patterns of renal cell carcinoma (RCC) in Benin City, Nigeria

\begin{tabular}{|c|c|c|}
\hline $\begin{array}{c}\text { Patterns of Renal cell carcinoma } \\
\text { (RCC) }\end{array}$ & Number of Cases & Percentage \\
\hline Clear cell carcinoma & 24 & $68.6 \%$ \\
\hline Papillary RCC & 11 & $31.4 \%$ \\
\hline
\end{tabular}

Table 5: Clinical Presentation of Renal Biopsies in Benin City, Nigeria $(n=69)$

\begin{tabular}{|c|c|c|}
\hline Presentation & occurrence & Percentage (\%) \\
\hline Intra-abdominal mass & 69 & $100 \%$ \\
\hline Nephrotic syndrome & 40 & 58.0 \\
\hline Weight loss & 37 & 53.6 \\
\hline Hypertension & 25 & 36.2 \\
\hline Dysuria & 19 & 27.5 \\
\hline Necroturia & 02 & 2.9 \\
\hline
\end{tabular}

\section{Discussion}

In general, renal tumors are uncommon in our society (Benin City, Nigeria). It has an occurrence of $69 / 19,123(0.36 \%)$ within the period under review. This finding is comparable to the report by Isah [12] in Sokoto state, Nigeria. It shows a renal tumor incidence of 0.3 percent of all tumors diagnosed during the study period. A similar observation was reported in Port Harcourt [14], Enugu [15], and Ile-Ife [16], thereby revealing a low occurrence in Nigeria. The youngest age of renal tumor case found in this study occurred in a 5-year old patient while the oldest age is a 62-year-old. The universal indicator for a renal biopsy from our record is intraabdominal mass 69/69(100\%). This report agrees with the documented study in Jos, Nigeria [17] showing $53 / 53(100 \%)$ occurrences. Carefully followed indicators are nephrotic syndrome and weight loss. These observations are similar to the report that serves as an indication for biopsy from registries in another part of the world [3]. Conversely, nephrotic range proteinuria is also seen as the most common indication for renal biopsies in a recent study that reviewed the profile of adults admitted to a nephrology unit in the Free State province of South Africa [18].

Notable literature [19] suggests that malignant renal tumors are more frequent in developed countries than in Africa. However, this observation may be exacerbated as there exist, a high number of cases of malignant renal tumors when compared to benign. It may be owed in part to the late presentation of the lesions to the hospital. Late presentation of lesions $78.9 \%$ in Nnewi has been reported [20]. Table 3 showed that malignant renal tumors are more common in males 38/53(71.7\%) when compared to females $15 / 53(28.3 \%)$ with a male to female ratio of about (3:1). Some centers in Nigeria [12] also charted a male to female ratio of approximately 2:1. The narrow rate in this study might relate to the indiscriminate exposure of both sexes (males and females) in Benin City, Nigeria to risk factors like occupational (e.g. textile workers, Dye workers, rubber and leather workers), chemicals, biologicals, and behavioral factors e.g. cigarette smoking [21]. The risk factors stated earlier may have an effect on different tribes with RCC in Benin City, Nigeria. Added report outside the country showed a wide disproportion of 4:1 ratio [21]. Earlier studies have reported the male dominance in the occurrence of a renal tumor; though, the reasons for the disparity remains unclear $[14,16]$. 
Congruently, higher proportions of malignant cases in males have also been reported in Port Harcourt [14], and Enugu [15], Nigeria; while, Badmus et al. [16] reported a preponderance of females.

RCC is the main malignant tumor in this study and is the most common occurring type in adults. Previous studies $[16,20,22]$ showed that RCC is the dominant type of malignant renal tumor in adults. These tumors are derivative of the renal tubular epithelium and hence they are located primarily in the cortex. The report has it that the risk of developing these tumors is higher in smokers, hypertensive and obese individuals [17], and those with occupational exposure to cadmium [12, 16, 20]. Smokers who are exposed to cadmium have an exceptionally high incidence of RCC [22]. It is comprehensible that clear cell carcinoma accounts for (68.6\%); papillary RCC (31.4\%) and chromophobe type has none. These results fall within the reported prevalence by Isah [12] where a record in Sokoto was entirely devoid of chromophobe type. It may be that chromophobe RCC is considered less aggressive than other forms [12]. Note: Papillary renal cell carcinoma and clear cell carcinomas appear to be more common in Africa (especially in Nigeria) than granular cell carcinomas and clear cell type that are predominant in North America. However, the reason for the disparity is unclear.

The high prevalence of malignant renal tumors in this study could be due in part to the point that UBTH, Nigeria serves as a referral center to neighboring states. It includes the Yoruba speaking (Ondo state) and other minority groups from Delta, Anambra and Kogi states respectively. In the United Kingdom, approximately eighty-five cases of kidney cancer are diagnosed each year in children (0-14years old) [23], with about three-quarter of it occurring in children under the age (5years). Our study agrees with the kidney cancer incidence statistics [23] by which all eleven cases of NBT in this study occurs in the age range of 0-10 years. It further confirmed that most common kidney tumors in childhood are Wilm's tumor or NBT [12,17]. Wilm's tumors also occur in adults; it is the third most common organ cancer in children younger than the age of 10years mostly between the ages of 2-5year old $[12,17]$. TCC is the least in occurrence, is the most common type of cancer affecting renal pelvis compared to squamous cell carcinoma, which has been published [23] and is seen mostly in adults $[24,25]$. All seven cases observed in this study occurred in male patients, which confirms that it is male predominant. However, a recent report in Ibadan [24] and Jos [25] Nigeria shows a changing trend. The report suggests that TCC of the urinary bladder is the predominant histology type [17] and thus agrees with our findings. The evolving trend may be attributed to changes in socio-economic status and increasing industrialization in Nigeria, thereby, exposing the vulnerable groups to more carcinogenic agents in the region.

\section{Conclusion}

The present study showed that malignant renal tumor is male dominant in Benin City, Nigeria. Renal cell carcinoma has the highest occurrence followed by nephroblastoma that occurs in childhood only. Transitional cell carcinoma occurs only in adults, while; clear cell carcinoma is the prevailing renal cell carcinoma histologic subtype seen in this study. The observations in our study are useful in showing the patterns, occurrence and histologic subtypes of renal tumors uncommonly encountered in this part of the world.

\section{Acknowledgements}

Authors appreciate the enormous support of the pathologist, Medical Laboratory Scientist (histotechnologist), resident and the data processing officers in UBTH Morbid Anatomy Department/ Histopathology Laboratory for their untiring co-operation. We also wish to acknowledge the magnificent support from the SHCCSW Research Group, University of Benin, Nigeria.

\section{References}

[1]. Fuiano G, Mazza G, Comi N, Caglioti A, De Nicola L, Iodice C, et al. Current indications for renal biopsy: a questionnaire-based survey. Am J Kidney Dis 2000; 35(3):448-57.

[2]. Borje L, Steven CC, Han Yong C, Didier J, Jung Eun J, Steffen W. The Epidemiology of Renal Cell Carcinoma. European Journal of Urology 2011; 60 (4): 29-36.

[3]. Naumovic R, Pavlovic S, Stojkovic D, Basta-Jovanovic G, Nesic V. Renal biopsy registry from a single center in Serbia: 20 years of experience. Nephrol Dial Transplant 2009; 24: 877-885

[4]. Woo KT, Chiang GS, Pall A, Tan PH, Lau YK, Chin YM, et al. The changing pattern of glomerulonephritis in Singapore over the past two decades. Clin Nephrol 1999; 52(2): 96-102.

[5]. Swaminathan S, Leung N, Lager DJ, Melton LJ 3rd, Bergstralh EJ, Rohlinger A, et al. Changing incidence of glomerular disease in Olmsted County, Minnesota: a 30-year renal biopsy study. Clin J Am Soc Nephrol 2006; 1(3): 483-487.

[6]. Ojo OS, Akinsola AA, Nwosu SO, Odesanmi WO. Pathological basis of chronic renal failure in Nigerians. An autopsy study. Trop Geogr Med 1992; 44(1-2): 42-46.

[7]. Okpechi IC, Swanepoel M, Duffield B, Mahala N, Wearne S, Alagbe, Z, et al. Patterns of renal disease in Cape Town South Africa: a 10-year review of a single-centre renal biopsy database Nephrol Dial Transplant 2010; 1(9):1-9.

[8]. Kumar V, Abbas AK, Fausto N. Robbins and Cotran Pathologic Basis of Disease. $7^{\text {th }}$ edition. India: Elsevier, a division of Reed Elsevier India Private Ltd; 2004.

[9]. Kovacs G. Molecular differential potential pathology of renal cell tumors. Histopathology 1993; 22:1-8.

[10]. Weiss LM, Gelb AB, Medeiros LJ (1995). Adult renal epithelial neoplasms. American Journal of Clinical Pathology. 103:624-635. 
[11]. Davis CJ, Mostofi FK, Sesterhenn IA (1995). Renal medullary carcinoma: The seventh sickle cell nephropathy. American Journal of Surgical Pathology. 19:1-11.

[12]. Isah RT, Sahabi SM, Adamu SN, Muhammad AT, Mungadi IA. Histopathological pattern of renal tumors seen in Usmanu Danfodiyo University Teaching Hospital Sokoto, Nigeria. African Journal of Cellular Pathology 2013; 1(1):9-13.

[13]. Simon P, Ramee MP, Boulahrouz R, Stanescu C, Charasse C, Ang KS, et al. Epidemiologic data of primary glomerular diseases in western France. Kidney Int 2004; 66(3): 905-908.

[14]. Seleye FD, Etebu EN, Jebbin NJ. A ten-year pathological study of renal tumors in Portharcourt, Nigeria. Annals of African Medicine 2006; 5(2): 64-67.

[15]. Aghaji AE, Odoemene CA. Renal cell carcinoma in Enugu, Nigeria. West African Journal of Medicine 2000; 19(4):254-8.

[16]. Badmus TA, Salako AB, Arogundade FA, Sanusi AA, Adesunkanmi A, Oyebamiji EO. Malignant renal tumors in adults: A TenYear Review in a Nigerian Hospital. Saudi Journal of Kidney Disease and Transplantation 2008; 19 (1):120-6.

[17]. Mandong BM, Iya D, Obekpa PO, Orkar KS. Urological tumors in Jos University Teaching Hospital, Jos, Nigeria (A Hospitalbased Histopathological study). The Nigerian Journal of Surgical Research 2000; 2 (3-4): 108-113.

[18]. Van-Rensburg BWJ, van Staden AM, Rossouw GJ, Joubert G. The profile of adult nephrology patients admitted to the Renal Unit of the Universitas Tertiary Hospital in Bloemfontein, South Africa from 1997 to 2006. Nephrol Dial Transplant 2010; 25: 820-824.

[19]. Sow M, Nkegoum B, Oyono JL, Nzokou A. Epidemiological and histological features of urogenital tumors in Cameroon. Prog Urology 2006; 16(1):36-9.

[20]. Mbaeri TU, Orakwe JC, Nwofor AM, Oranusi CK, Ulebe AO. Malignant renal tumors in Nnamdi Azikiwe University Teaching Hospital, Nnewi, Nigeria. Nigerian Journal of Medicine 2012; 21(4): 377-380.

[21]. Lynch CF, Cohen MB. Urinary system. Cancer 1995; 75(1): 316-329.

[22]. Edward FG. Rapid Review Pathology. 2nd edition. India: Elsevier, a division of Reed Elsevier India Private Limited; 2007.

[23]. Kidney cancer incidence statistics. Cancer Research, 2010. Available from http//www.cancerresearchuk.org. [Last cited on 2013 July 25].

[24]. Thomas JO, Onyemenen NT. Bladder carcinoma in Ibadan: A changing trend? East Afr Med J 1995; 72: 49-50.

[25]. Mandong BM. Carcinoma of the Urinary Bladder in Jos, Nigeria. Nig Med Pract 1997; 33:33-34. 